\title{
THE OUTSTANDING UNIVERSAL VALUE OF THE HISTORIC COLONIAL CENTRE OF THE CITY OF GRACIAS (HONDURAS)
}

\author{
M. J. Viñals ${ }^{1, *}$, L. Teruel ${ }^{1}$, P. Alonso-Monasterio ${ }^{1}$ \\ ${ }^{1}$ Research Centre PEGASO, Universitat Politècnica de València, Valencia, Spain - (mvinals, dteruel, paualfer)@upv.es
}

Commission II - WG II/8

KEY WORDS: Heritage, Tentative List, Spanish Colonial City, Historic centre, Gracias (Lempira, Honduras)

\begin{abstract}
:
This paper analyses the outstanding universal values, integrity, and authenticity of the city of Gracias (Honduras), as well as its protection and heritage management tools. The main objective is to demonstrate that Gracias meets the UNESCO requirements to qualify as a candidate for inclusion in the International List of the World Heritage Convention (1971). Gracias is a colonial Spanish city, founded in 1536, in the region of Lempira. It had great productive, strategic and administrative importance in Central America, demonstrated in part by its hosting of the 'Audiencia de los Confines'. The 'Audiencia' was the highest court of the Spanish Crown with jurisdiction over the current republics of Guatemala, Belize, El Salvador, Honduras, Nicaragua, Costa Rica and the region of Chiapas. The aim of this court was to represent the interests of the indigenous people in these areas. An on-site analysis, diagnosis and assessment of the heritage elements was carried out from architectural, urban planning, historical, and intangible heritage perspectives. Additionally, other similar sites in Central America have been analysed for comparison. Results show that this city meets criterion iv of the World Heritage Convention: 'an outstanding example of a type of building, architectural or technological ensemble or landscape which illustrates (a) significant stage(s) in human history'. Furthermore, the city's heritage assets are wellpreserved and most of them remain functional; the indigenous culture is alive; and planning, conservation and managing tools are in use. Currently, Gracias maintains its harmony and life and its respect for the natural environment, creating a cultural landscape that has been maintained for almost 500 years.
\end{abstract}

\section{INTRODUCTION}

The historic colonial centre probably represents one of the most important cultural heritage resources of Latin America. These are generally well preserved remains of ancient Spanish or other European countries, often forming the essence of a city's urban identity and in many cases of outstanding universal value. Currently, they represent a useful starting point for coordinating action to revitalize the heritage and to recognize its potential not only in terms of cultural value but also in terms of functional, economic or social values.

Accordingly, historic colonial centres have often been nominated as UNESCO World Heritage Sites (WHS), demonstrating international acknowledgement that heritage sites with significant importance should be protected in order to prevent the loss of cultural and natural significance.

Among the most complex frameworks to tackle in heritage management, are the urban sites, because they involve a large and diverse number of actors, contexts, and resources, all of which interact in managing a city and its development.

The criteria for a historic centre to be considered for inclusion in UNESCO's World Heritage List are complex, considering as essential not only the implementation of technical heritage management tools but also the commitment of cities themselves. Nevertheless, inclusion in UNESCO's World Heritage List can ensure the long-term preservation of the sites, and often facilitates translation of these issues into local, social, and urban policies with regards to the concerns of their inhabitants.
This paper focuses on the analysis of the city of Gracias, Honduras to consider and answer the question of whether it meets the conditions required of a property in order to be deemed of Outstanding Universal Value (OUV) (UNESCO Word Heritage Centre, 2011); integrity and/or authenticity, along with heritage protection and management tools to ensure its safeguarding. Therefore, the main objective is to demonstrate that Gracias meets the UNESCO requirements to apply as a candidate for inclusion in the International List of the World Heritage Convention (UNESCO, 1972).

This paper describes research carried out in the course of elaboration of a Sustainable Tourism Strategic Plan of Colosuca Destination (Viñals et al., 2016), designed for the Mancomunidad Colosuca.

\section{CONCEPTUAL FRAMEWORK}

According to the UNESCO Operational Guidelines for the Implementation of the World Heritage Convention (UNESCO, 2019), the statement of Outstanding Universal Value is an essential tool for the inclusion of a property in the World Heritage List.

Outstanding Universal Value (OUV) is defined as the:

Cultural and/or natural significance which is so exceptional as to transcend national boundaries and to be of common importance for present and future generations of all Humanity.

* Corresponding author 
To this end the nominated property must meet at least one of the ten criteria of OUV described in the Operational Guidelines. Criterion $\mathrm{i}$ to vi refer to cultural properties, criterion vii to $\mathrm{x}$ refer to natural properties. Likewise, the property must meet the conditions of authenticity and/or integrity (UNESCO Word Heritage Centre, 2011).

The assessment of the conditions of integrity highlights the unitary and intact character of the described attributes of the property. Integrity can also relate to the size of the property (sufficient size to continue to represent the values) and to any threats affecting the property. The assessment of the conditions of authenticity determines whether what is presented is a true representation of the original state. It refers to the credibility of the property, if the rationale for its OUV criteria is true and if their attributes are authentic.

\section{METHODOLOGY}

Throughout the development of this work, several methods of scientific research were used including direct observation, the study of relevant scientific literature (journals, books, websites, etc.) and other sources (UNESCO documents, planning and managing dossiers, official reports, etc.), in order to find the necessary information and data for already listed World Heritage Sites and the procedures they followed to meet the UNESCO criteria.

A benchmarking approach to comparative analysis with similar World Heritage Sites (historic centres with similar origins and/or attributes) allows us to determine the direction in which the designation of Gracias should go. Then, this paper analysed the outstanding universal values, criteria, authenticity, and integrity of these sites from the official UNESCO data at its World Heritage List website (UNESCO, 2020a).

The analysed case studies are Centro Histórico de Santa Cruz de Monpox (Colombia), Barrio histórico de la ciudad de Colonia del Sacramento (Uruguay), Antigua Guatemala (Guatemala), and Ciudad Colonial de Santo Domingo (República Dominicana).

It should be noted that no comparative analysis in Latin America has been developed so far capable of showing the representativeness of its cultural and natural heritage in the World Heritage List. It was in 2008 that, for the first time, in the technical report of the Villa Protectora de San Miguel y el Santuario de Jesús Nazareno de Atotonilco (UNESCO, 2020b), a comparative analysis was developed, based on the urban types of the hispoanoamerican historical cities in relation to this Mexican Villa. Years later, Castillo (2018) also performed a comparative analysis of the colonial historical centers.

\section{THE HISTORICAL CENTRE OF GRACIAS}

The town of Gracias (Figure 1), as it is recognised today, was founded in the 16th century by the Spaniards. It is located in the Lempira region, in the west of Honduras, in a mountainous area attached to the Sierra Sur, just at the foot of Celaque which is the highest relief of Honduras (2,849 $\mathrm{m}$ above sea-level) characterized by the presence of cloudy forests. This mountain constitutes a natural icon of great significance for the country.

The region is affected by earthquakes which throughout history have left their mark on the territory (Rivera Tovar, 2009).

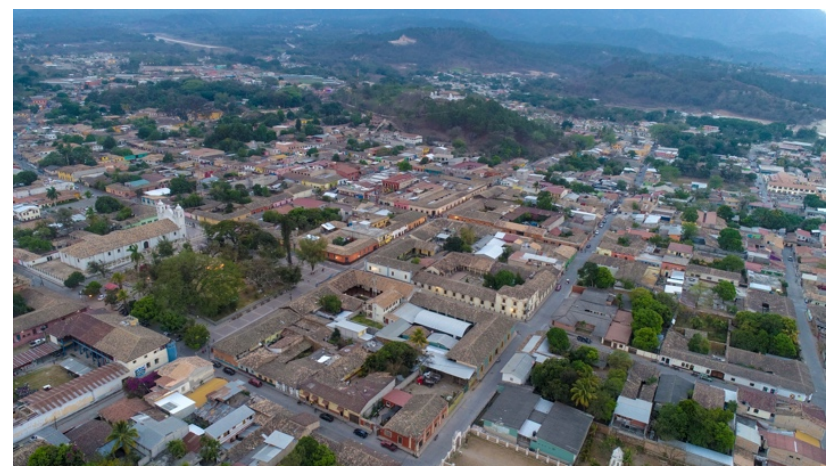

Figure 1. Aerial view of the historical centre of Gracias (Author: U. Alvarado, 2019).

After two previous settlements, the town was definitively located in the Gracias' Valley, crossed by the river Mejocote or Río Grande de Gracias, which is a tributary of the Ulúa, which flows into the Atlantic. The Río Grande is fed by more than 50 springs and streams flowing from Celaque, among which is the Arcagual, the main water supply provider of Gracias.

When Spanish arrived in the area, the region was sparsely populated by the indigenous Lenca people who still live in the town and its nearby mountains. It is true that the Lenca population has been waning over time, but not so its culture which permeates the life of the town of Gracias and has tangible expressions and manifestations especially relevant in the religious and social spheres. Thus, the legends and current religious rituals are the result of a centennial coexistence that is reflected in a syncretism of the Christian religion and the animist beliefs of the Lencas. In fact, the most celebrated festivities of the town are mostly Lenca (Guancasco, celebrating the National Day in honour of the cacique Lempira, etc.). Handicrafts, especially pottery, gastronomy, and other traditional customs meanwhile are also Lenca heritage (Joya, 2011).

Spanish Captain Gabriel de Rojas founded the first city on the site of current day Gracias in 1530. This first settlement was abandoned and refounded in 1536 by Gonzalo de Alvarado y Juan de Chávez (Fiallos, 1989). This urban centre had great administrative, productive and strategic importance throughout Central America, due to agriculture, mining and livestock. Of particular importance and relevance was the existence of opal mines located in the municipality of Erandique that were under the administration of Gracias, in addition to the cultivation of indigo, tobacco and cocoa.

Shortly after the founding of the town, in 1544, the 'Audiencia de los Confines' was established in the town, next to the dependencies of the Mercedarian convent. This gives us an idea of the administrative importance of the town in the context of Central American. The 'Real Audiencia de los Confines' (officially called 'Real Audiencia y Chancillería de los Confines de Guatemala y Nicaragua') was the highest court of the Spanish Crown in the territory of the so-called Kingdom of Guatemala, also known as the Captaincy General of Guatemala, with jurisdiction over the present Republics of Guatemala, Belize, El Salvador, Honduras, Nicaragua and Costa Rica, as well as the Mexican state of Chiapas. This court of justice to guard the interests of the indigenous people, was created by Real Cédula (Royal decree) on the 3rd of September 1543 and was in charge of administering the 'New Laws' (Rubio Mañé, 1955). In these laws, the influence of Fray Bartolomé de las Casas was evident, so that indigenous peoples were 'governed in justice'. 
Gracias evolved harmoniously throughout its history, maintaining its urban structure, its traditions and its population growth rate. Until the 19th century it was an important city in the context of the colonial system but in the 20th century there was a movement of families towards other nearby regions that began to stand out for their commercial development, among them the neighboring town of Santa Rosa de Copán, in the current department of Copán, where tobacco cultivation ensured the prosperity of western Honduras.

Nowadays, Gracias is a commercial centre with an agricultural base, with coffee the main marketable product due to a welldeserved recognition of its quality at international level. The natural and cultural heritage of this town is now receiving growing attention from tourists, both national and international, who seek the naturalness of its landscapes and the authenticity of the town and its inhabitants.

In addition to the historical importance of the town in the Central American context, it is worth noting the architectural and urban value of it, since it is a significant, representative, authentic and integral example of architecture and urbanism that is linked to the early times of the Spanish colony. This heritage is preserved in perfect condition and still performs the functions for which it was created.

The historic centre represents the 16th century core, from which an orthogonal layout is established and expanded with a plot of colonial dwellings, consisting of an interior courtyard and large wooden, arcaded, roofed corridors, around which the interior spaces are distributed. The buildings are constructed with local materials and traditional techniques, with mud brick walls raised on small stone plinths, and wooden or tiled roofing.

The architectural analysis of the town was recently well documented in the historical evolution established in the 20142025 Urban Development Plan of Gracias (Ceballos et al., 2014). Thus, the first constructions of the foundational period were concentrated around the religious buildings, linked mainly to the Mercedarian Order, and the administrative buildings of the colony, located around the Plaza Central. In 1544 the 'Audiencia de los Confines' took up residence in the old Mercedarian convent. Its main facade is still conserved next to the Church of San Marcos.

The 17th and 18th centuries are notable for the construction of colonial buildings like the Church of La Merced in the Central American baroque style, considered to be one of the oldest colonial churches in Honduras. Later, the Church of Santa Lucía was built, and is the current location for the Guancasco celebrations, the main Lenca festival, and also the Church of San Marcos, which is the most important urban landmark in the city and is located in the vicinity of the Plaza Central.

In the 19th century, the Fort of San Cristóbal was constructed in its current form. It is located geostrategically at the top of the hill of the same name, to defend the town against the threats of invasion that existed from Guatemala and El Salvador in the framework of the struggles between conservatives and liberals. It is also the site of the Old Penal Centre, currently used as the headquarters of the Local Police.

In the 20th century, between 1900 and 1920, the Municipal Market was built, following the standards of colonial architecture.
In 1915, an important earthquake occurred that caused serious damage to the built heritage of the municipality. However, the buildings were restored, largely in their original style, but also incorporating some neoclassical influences that were the usual at the time. One example of this is the case of the Church of San Marcos. Finally, in 1930 the Church of San Sebastián was built in its present location, since the original hermitage of the 18th century located in front of the Church of La Merced was demolished due to the damage suffered in telluric movements during 1870. The same Guancasco festival as mentioned above is also celebrated here, coinciding with the festivities of San Sebastián (20th of January), the patron saint.

Since the end of the 20th century, continuning to the present day, the town's residential housing in the extra-urban areas has grown. On the other hand, the heritage buildings conserve their original function, as in the case of the Central Plaza. This square was originally a public meeting space, where on Sundays the market of agricultural and craft products was held, royal justice was imparted, celebrations were performed and the latest news from Spain was proclaimed. Today it is a public space surrounded by the most important public buildings, such as the Municipal Palace, the Old Penal Centre, Church of San Marcos and Government buildings. It retains its authenticity by way of it still being used for the functions for which it was originally conceived. It continues to be a point of reference for the town, where the main social activities take place. For these reasons, the town offers a representative image of the life of the colonial agricultural producing towns.

The continuation of the residential use of the historical centre of Gracias is another aspect that reflects the strong cultural tradition that the Gracian society has maintained since its time as a colony. The city, despite its growth, has respected the original architectural style ensuring that its urban image has not changed since its foundation. The architecture and urban layout conserve their original character from the time of the tow's inception, and still house its essential activities. Today, it maintains its harmony and lifestyle, and continues to dialogue with the urban environment thanks to the containment of its growth and its respect for the natural environment, creating a cultural landscape that has endured for almost 500 years.

\section{RESULTS OF THE ANALYSED CASE STUDIES}

\subsection{Historic Centre of Santa Cruz de Mompox (Colombia)}

According to the information presented in the UNESCO Word Heritage List (UNESCO, 2020c), this city was founded in 1540 on the banks of the River Magdalena and played a key role in the Spanish colonization of northern South America. From the 16 th to the 19th century the city developed parallel to the river, with the main street acting as a dyke. The historic centre has preserved the harmony and unity of the urban landscape. Most of the buildings are still used for their original purposes. This historical centre was designated as a World Heritage Site in 1995 under the criteria iv ${ }^{1}$ and $\mathrm{v}^{2}$.

\footnotetext{
Criterion iv: to be an outstanding example of a type of building, architectural or technological ensemble or landscape which illustrates (a) significant stage(s) in human history.

Criterion v: to be an outstanding example of a traditional human settlement, land-use, or sea-use which is representative of a culture (or cultures), or human interaction with the environment especially when it has become vulnerable under the impact of irreversible change.
} 
In relation to criterion $i v$, it was argued that this historical centre was an integral part of the processes of colonial penetration and domination during the Spanish conquest and of the growth of communications and commerce during the 17 th to early 19 th centuries

Criterion $v$ highlighted the special circumstances of the development of the town, which grew freely and longitudinally following the sinuous path of a road roughly parallel to the river, have given it a special quality with few parallels in the region of northern South America. The subsequent economic decline and the remarkable state of preservation that resulted, confers a further dimension on this quality, making it the region's most outstanding surviving example of this type of riverine urban settlement.

The integrity was demonstrated from the existence of all the elements necessary to express its OUV and from the sufficient size of the property to adequately ensure the complete representation of the features and processes that convey the property's significance.

The authenticity was based on the loss of its economic importance in the 19th century, thus its historic centre has not been subjected to the pressures of redevelopment that have affected other towns of this type in northern South America. The historic centre's original street pattern has been preserved intact, along with a large proportion of its earlier buildings. Its level of authenticity is therefore high in terms of its setting, forms, materials and construction techniques. Most of the buildings are still being used for their original purposes. The historic centre has therefore retained its original residential function and is generally in a good state of preservation.

Regarding protection and management requirements, this historic centre presented a distribution of the ownership among the Catholic Church, private owners, institutions and local authorities. It was declared a National Monument in 1959, the law covers the basic principles for the management and protection of the cultural heritage. It has been regulated by a municipal building code since 1970, through which all construction work within the historic centre is strictly controlled. There are legal provisions to maintain and protect the urban and architectural heritage while adapting to new conditions and the needs of development. The National Monuments Council, in March 1994, approved some rules to regulate the urban centre of Mompox.

\subsection{Historic Quarter of Colonia del Sacramento (Uruguay)}

Founded by the Portuguese in 1680 on the Río de la Plata, the city was of strategic importance in resisting the Spanish. After being disputed for a century, it was finally lost by its founders. The wellpreserved urban landscape illustrates the successful fusion of the Portuguese, Spanish and post-colonial styles. This historical quarter was designated as a WHS in 1995 under the criterion iv (UNESCOd, 2020).

Thus, its OUV was based on the remarkable testimony of its urban layout and its buildings from the times of European colonial settlements, in particular during the seminal period at the end of the 17 th century.

The integrity was demonstrated by maintaining its original structure and the scale of both its urban structures and of its buildings. Stressing the fact that the plan coincides exactly with that of the Portuguese city "Nova Colonia do Sacramento", notably with the period of greatest splendour corresponding to the first half of the 18th century. All the elements necessary for the expression of the values of the Historic Quarter of Colonia del Sacramento are included in the designated area and its buffer zone.

In relation to authenticity, it was argued based on the evidence of its credibility and original characteristics.

These historic quarters are listed as National Historic Monuments. They thus benefit from the highest protection under the national Uruguayan law in force.

\subsection{Historic Centre of Antigua Guatemala (Guatemala)}

Antigua, the capital of the Captaincy-General of Guatemala, was founded in the early 16th century. Built 1,500 m above sea-level, in an earthquake-prone region, it was largely destroyed by an earthquake in 1773 but its principal monuments are still preserved as ruins. Throughout three centuries the city, which was built on a grid pattern inspired by the Italian Renaissance, acquired a number of superb monuments. This historical centre was designated as a WHS in 1979 under the criteria $\mathrm{ii}^{3}$, $\mathrm{iii}^{4}$ and iv (UNESCOe, 2020).

According to the criterion ii, Antigua Guatemala contained living traces of Spanish culture with its principal monuments, built in the Baroque style of the 18th century preserved today as ruins. Antigua Guatemala was a centre for the exportation of religious images and statues to the rest of the American continent and to Spain during the 17 th and 18 th centuries.

Regarding criterion iii, Antigua Guatemala was one the earliest and outstanding examples of city planning in Latin America in which the basic grid plan, dating from 1543, has been maintained. Its religious, private and government buildings are outstanding examples of Spanish colonial architecture in Antigua.

Criterion iv was based on the many churches and monasteries that testify to the influence of the Christian church, during the colonial period, on every aspect of daily life in the city. Moreover, Antiguan Baroque style developed in this area is a regional adaptation of the Baroque style designed to withstand earthquakes which are common in the region.

The integrity was based on its 16th century layout and the physical integrity of most of its built heritage. The relocation transfer of the capital after the 1773 earthquake and the abandonment of the area by most of its population permitted the preservation of many of its monumental Baroque style buildings as ruins.

Authenticity was maintained thanks to the partial abandonment of the city in 1776, and the regulations prohibiting the repair and construction of new buildings. The city's 16th century Renaissance grid pattern and Baroque style monumental buildings and ruins have survived along with cobblestone streets, plazas with fountains, and domestic architecture. Recently, some of the original residences have been fully restored, following a neo-colonial or 'Antigua Style'.

Criterion ii: to exhibit an important interchange of human values, over a span of time or within a cultural area of the world, on developments in architecture or technology, monumental arts, townplanning or landscape design.

4 Criterios iii: to bear a unique or at least exceptional testimony to a cultural tradition or to a civilization which is living or which has disappeared. 
Regarding protection and management requirements, legal protection for Antigua Guatemala was established in 1944, when the city was declared a National Monument. The PanAmerican Institute of Geography and History declared it an American Historical Monument in 1965. The establishment of the "National Council for the Protection of Antigua Guatemala" in 1972 created an institution responsible for the protection and restoration of the city's monuments.

\subsection{Historic Colonial Centre of Santo Domingo (República Dominicana)}

After Christopher Columbus's arrival on the island in 1492, Santo Domingo became the site of the first cathedral, hospital, customs house and university in the Americas. This colonial town, founded in 1498, was laid out on a grid pattern that became the model for almost all town planners in the New World. This historical centre was designated as a WHS in 1990 under the criteria ii, iv and vi (UNESCOf, 2020).

Criterion ii was based on the strong influence of the colonial city on the development of the cities of the Caribbean and the American continent. Its grid pattern and its Plaza Mayor have served as a model for new cities in the Americas. Its institutional buildings dating from the 16th century, have served as references for future developments.

Criterion iv was considered to be satisfied by the intact urban structure which conserves much of the regularity of its grid layout, adjusted here and there to topographical imperatives, as well as the original width of its streets. Its monumental buildings that date from the beginning of the 16th century, bear witness to the decline of Spanish Gothic and the appearance of the first indications of the Renaissance, as is eloquently illustrated in its cathedral.

Criterion $v i^{5}$ refers to the importance of the universal events which took place in Santo Domingo (expeditions and conquests of new lands left from this point); the spread of evangelization and the first Leyes de Indias (Laws of the Indies) which were proclaimed and enforced in this city.

The Integrity requirement was considered to be satisfied thanks to the well preserved area enclosed within its walls, practically untouched from colonial times, the extension of its territory, its grid layout and most of its architectural monumental structures. Apart from rare but dramatic exceptions, it has retained its traditional scale, the width of the streets, the plots and heights of the buildings. Throughout its historical development, it has incorporated architecture of various eras with their forms, styles, materials and construction methods that have enriched the knowledge and interpretation of its economic, social and cultural development as a living historical centre.

Regarding authenticity, the Colonial City of Santo Domingo has retained intact its original perimeter, conserving most of its walls and forts. As aforementioned in the case of integrity, the urban grid plan, the plots and original width of its streets are conserved, for the most part, enabling a credible interpretation of the city. In addition, its small-scale architectural expression highlights its volumetric homogeneity.

Criterion vi: to be directly or tangibly associated with events or living traditions, with ideas, or with beliefs, with artistic and literary works of outstanding universal significance. (The Committee considers that this criterion should preferably be used in conjunction with other criteria).
The protection of this city was ensured thanks to a vast number of nationally enforced laws and decrees, and through municipal standards and provisions that consolidate its overall vision and the preservation of its elements. Moreover, an Integral Revitalization Plan for the Colonial City of Santo Domingo was approved by the Municipality by Notice $08-2011$.

\begin{tabular}{|c|c|c|c|c|}
\hline $\begin{array}{l}\text { Historic } \\
\text { Centre }\end{array}$ & \begin{tabular}{|l} 
Criteri \\
a
\end{tabular} & Integrity & Authenticity & $\begin{array}{l}\text { Protection and } \\
\text { management }\end{array}$ \\
\hline $\begin{array}{l}\text { Mompox } \\
\text { (Colombia) } \\
\text { Founded } \\
1540 \\
\text { WHS } 1995\end{array}$ & $\begin{array}{l}\text { iv } \\
\mathrm{v}\end{array}$ & $\begin{array}{l}\text { All the } \\
\text { elements } \\
\text { necessary to } \\
\text { express its } \\
\text { OUV } \\
\& \text { with the } \\
\text { sufficient } \\
\text { size }\end{array}$ & $\begin{array}{l}\text { Setting, } \\
\text { forms, } \\
\text { materials } \\
\text { and } \\
\text { construction } \\
\text { techniques. } \\
\text { Most with } \\
\text { their } \\
\text { original } \\
\text { purpose } \\
\end{array}$ & $\begin{array}{l}\text { National } \\
\text { Monument } \\
(1959) \\
\text { Urban centre } \\
\text { regulations } \\
\text { (1994) } \\
\text { Municipal } \\
\text { building code } \\
(1970)\end{array}$ \\
\hline $\begin{array}{l}\text { Colonia del } \\
\text { Sacramento } \\
\text { (Uruguay) } \\
\text { Founded } \\
1680 \\
\text { WHS } 1995\end{array}$ & iv & $\begin{array}{l}\text { Plan } \\
\text { coincides } \\
\text { with that of } \\
\text { Portuguese } \\
\text { city 'Nova } \\
\text { Colonia do } \\
\text { Sacramento' }\end{array}$ & $\begin{array}{l}\text { Credibility } \\
\text { and original } \\
\text { characteristi } \\
\text { cs }\end{array}$ & $\begin{array}{l}\text { National } \\
\text { Historic } \\
\text { Monument } \\
(1971)\end{array}$ \\
\hline $\begin{array}{l}\text { Antigua } \\
\text { Guatemala } \\
\text { (Guatemala) } \\
\text { Founded } \\
\text { early } 16^{\text {th }} \\
\text { century } \\
\text { WHS } 1979\end{array}$ & $\begin{array}{l}\text { ii } \\
\text { iii } \\
\text { iv }\end{array}$ & $\begin{array}{l}\text { 16th century } \\
\text { layout and } \\
\text { the physical } \\
\text { integrity of } \\
\text { most of its } \\
\text { built } \\
\text { heritage }\end{array}$ & $\begin{array}{l}\text { Renaissance } \\
\text { grid pattern } \\
\text { and } \\
\text { Baroque } \\
\text { style } \\
\text { monumental } \\
\text { buildings } \\
\text { have } \\
\text { survived }\end{array}$ & $\begin{array}{l}\text { National } \\
\text { Monument } \\
(1944) \\
\text { American } \\
\text { Historical } \\
\text { Monument } \\
(1965) \\
\text { National } \\
\text { Council for } \\
\text { Protection } \\
(1972)\end{array}$ \\
\hline $\begin{array}{l}\text { Santo } \\
\text { Domingo } \\
\text { (Rep. } \\
\text { Dominicana } \\
\text { ) } \\
\text { Founded } \\
1498 \\
\text { WHS } 1990\end{array}$ & $\begin{array}{l}\text { ii } \\
\text { iv } \\
\text { vi }\end{array}$ & $\begin{array}{l}\text { The area } \\
\text { surrounded } \\
\text { by its walls } \\
\text { is preserved } \\
\text { almost } \\
\text { unaltered }\end{array}$ & $\begin{array}{l}\text { Grid plan, } \\
\text { plots and } \\
\text { original } \\
\text { width of its } \\
\text { streets are } \\
\text { conserved }\end{array}$ & $\begin{array}{l}\text { Vast number } \\
\text { of national } \\
\text { laws and } \\
\text { decrees } \\
\text { Municipal } \\
\text { standards } \\
\text { Integral } \\
\text { Revitalization } \\
\text { Plan (2011) } \\
\end{array}$ \\
\hline
\end{tabular}

Table 1 presents the summary of the main results of the comparative analysis of WHS historic centres with similar origins similars to Gracias.

\section{JUSTIFICATION OF THE OUTSTANDING} UNIVERSAL VALUE OF GRACIAS

\subsection{Criteria}

The historic centre of Gracias complies with criterion iv for the inclusion of cultural properties in the World Heritage List (UNESCO World Heritage Centre, 2019):

To be an outstanding example of a type of building, architectural or technological ensemble or landscape which illustrates (a) significant stage(s) in human history.

This is because the urban layout and the heritage buildings that constitute the historic centre of Gracias present an outstanding historical, urbanistic and architectonic significance since they are elements related both architecturally and socially to the first years of the colonization of Central America (16th century) and, in particular, related to the rights of indigenous peoples ('Audiencia de los Confines'). 
Those elements reflecting this significance are currently preserved in perfect condition and are still 'alive', they have evolved over time, but always performing the function for which they were created originally, and the local population continues to use them in the same way it has always done; hence, its credibility and veracity.

The restorations carried out to repair the damages caused by earthquakes have always followed the canons of Spanish colonial architecture with certain adaptations of neoclassical style but have been made following traditional constructive techniques and using the same autochthonous materials employed in origin. Therefore, the significance and intrinsic value of the historical centre (urban structures, layout of the streets, historical sites, traditions, expressions of the local population and the inhabitants' awareness of their natural resources, etc.) are perfectly recognisable and interpretable today. Thus, it can be affirmed that this historic centre reliably transmits its outstanding universal value.

\subsection{Integrity and Authenticity}

The historic centre of Gracias and its buffer area have maintained since the 16th century the original colonial urban planning structure and the main colonial buildings. Currently they present an integral and unaltered urban image thanks to a harmonious evolution over the years.

The boundaries of the historic centre are clearly defined (Figure 2). It occupies six blocks around the Plaza Central. This space has not been altered and coincides with the original extension that it had in the 16th century (perimeter, width of the streets, extension of plots, height of buildings, etc.).

The proposed surface to be designated as a WHS is of sufficient size to ensure the complete representation of the urban characteristics (Renaissance urban layout) and architectural features (existence of all original buildings in good condition and maintaining integrity) that confer significance to this colonial town.

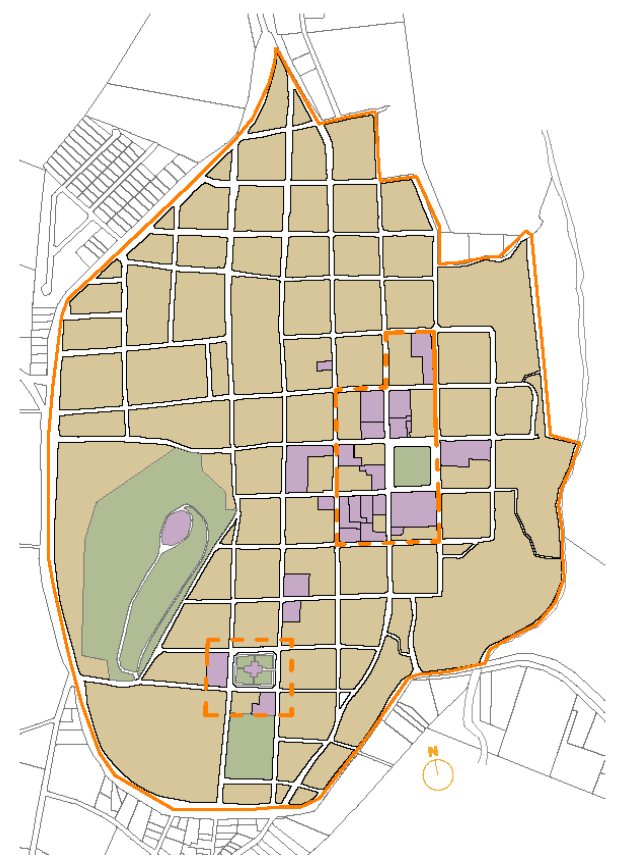

Figure 2. Skeched plan of the town of Gracias (Lempira), including the proposed area to be designated as a World Heritage Site (in dashed line). Source: Authors' own figure.
In addition, the development over time has contributed to the maintenance of the urban scale in very harmonious proportions. All this makes the size of the historic centre ideal in terms of maintaining the town's OUV, being able to interpret in it the daily life of a commercial town that has maintained its activity from the colonial times and which continues today.

It should also be highlighted that this historic centre is fully contextualized within its immediate urban environment because it maintains harmony with adjacent buildings and urban structures which, in fact, constitute the legally established buffer area.

The natural context of this colonial town (Mountain of Celaque and Sierra de Puca) presents a pristine outstanding and magnificent natural landscape, and it is exceptional in terms of biodiversity. This natural framework constitutes a scenic universal value in itself, due to its natural integrity and its quality, which conveys the same original setting that was at the time of the foundation of the town.

In relation to the social structure, it constitutes its own intangible living heritage. The social structure is based, as mentioned before, on uses, representations, expressions, knowledge and traditional techniques which are unique and authentic, a result of the cultural fusion of Spaniards and Lenca population. This confers on the whole an originality and uniqueness that does not exist elsewhere, and hence it is a distinctive feature of identity.

Considering all these factors together demonstrates why Gracias stands out as a town with great symbolic value. However, it should be pointed out that this is a situation characterized by its exiguity, restricted location, fragility and ethnicity, which places it in a weak position that must be properly addressed to avoid a loss of social identity.

The authenticity of the historic centre of Gracias is based on the genuineness and veracity of its urban layout and its buildings, and on the functionality of urban and social structures, that have survived despite damage from earthquakes. Furthermore, buildings have been restored following their original design, with traditional techniques and autochthonous materials; without altering their significance and original image, preserving their attributes and their functions.

Currently, the dwellings present perfect conditions of habitability, and the public spaces (market, squares, municipal buildings, etc.) persist as places of reference for the Gracian people who interact daily with and within its heritage assets, considering them fundamental part of their lives. This fact has fostered an important sense of belonging and feeling of appropriation. This functional value is also closely linked to the economic value because the continuity of the original and traditional functions of the historic centre have reinforced its significance.

As for social authenticity, it must be remembered that daily life is based on social groups and is the result of the fusion of two cultures that have evolved side by side. It is true that the Lenca population is currently sparse, but its legacy is authentic. These are manifestations of ethnicity realted mainly to their cultural (rather than phenotypic) traits and are recognized in the cultural expressions that characterize and make unique the region and the town, with which the Gracian people identify themselves; so their transmission is guaranteed meanwhile its cultural framework endures: along with the centre, its buildings and the resulting lifestyle. 
It is, therefore, a heritage with an historical, urbanistic and architectural intrinsic value, but also social, which has had the capacity to transmit its significance, where its values are clearly recognizable; hence, making it authentic, credible and evident.

\subsection{Protection and management requirements}

The area with OUV, required for the designation as a WHS, overlaps with that defined in 1997 as the historic centre of Gracias, then protected under the figure of a 'National Monument'. This is a national declaration, by Agreement No. 168 of 4th June, 1997 of the State Secretary in the Office of Culture, Arts and Sports.

This declaration includes the six blocks around the Plaza Central (5.47 ha), and the historic area of San Sebastián, formed by the square of the Church of San Sebastián and constructions around (1.92 ha) (Figure 2). The buffering area extends to the road that accesses the town, which reaches 81.48 ha in total. In this area a high percentage of the original residential use has been maintained throughout the urban development process of the town.

Public or private work in this area is prohibited where this would alter or damage designated national monuments, without prior authorization of the Honduran Institute of Anthropology and History (IHAH), thus ensuring its conservation. To this end, the criteria for the management of the historic centre are formulated, through the Regulation for the Protection of the historic centre of the town of Gracias, of May 2007, and the responsibility for this lies with the Municipality, after obtaining the opinion of the Office of Historical Ensembles, also based in the city of Gracias.

In addition to the national protection of the historic centre of Gracias, the Honduran Institute of Anthropology and History (IHAH), together with the State Secretary in the Office of Culture, Arts and Sports, are responsible for the protection of heritage. This institution already drafted an inventory, which included 27 buildings directly related, in terms of situation or function, with the life of the town, and on which it exerts a direct control before any action may take place which affects their fabrics. This is regulated according to the Law of Protection of the Cultural Patrimony (Decree 220-97), approved by the National Congress and published in La Gaceta of the Republic of Honduras on 21st February 1998.

Afterwards, during the period 2008-2016, different regulations of urban development have been approved and various restoration interventions have been carried out.

On the other hand, the natural areas surrounding the Gracias valley enjoy the categories of National Park for Celaque (1987) and Wildlife Refuge for the Mountain of Puca, declared under Decree 87-87 of the National Congress. In addition, the Celaque Mountain has been designated as a UNESCO Biosphere Reserve under the name of 'Cacique Lempira, Lord of the Mountains' since 2015, due to its important ecological value. Beyond its naturalistic value, this natural space has an emotional value because it has been the habitat of the Lenca people who lived in this area prior to the arrival of the Spaniards.

Table 2 presents the different management instruments available to the town of Gracias for conserving and protecting both natural and cultural assets, as well as those for cultural and tourism revitalization.

\begin{tabular}{|c|c|c|}
\hline $\begin{array}{l}\text { DOCUMENT / } \\
\text { DATE }\end{array}$ & COMPETENCE & $\begin{array}{l}\text { SUPPORTING } \\
\text { INSTITUTION }\end{array}$ \\
\hline $\begin{array}{l}\text { National Cultural } \\
\text { Heritage } \\
\text { Protection Act } \\
\text { (Decree N²20- } \\
\text { 97) / } 1997\end{array}$ & National & $\begin{array}{l}\text { Honduran Institut } \\
\text { for Anthropology } \\
\text { and History (IHAH) }\end{array}$ \\
\hline $\begin{array}{l}\text { Tourism } \\
\text { Development } \\
\text { Plan. Strategic } \\
\text { Plan for Tourism } \\
\text { Development of } \\
\text { the Lenca Route / } \\
\text { 2004 }\end{array}$ & National & PNUD \\
\hline $\begin{array}{l}\text { Interpretation } \\
\text { Program for the } \\
\text { Mancomunidad } \\
\text { Colosuca } / 2005\end{array}$ & $\begin{array}{l}\text { Mancomunidad } \\
\text { Colosuca }\end{array}$ & $\begin{array}{l}\text { Honduran Institut } \\
\text { for Tourism (IHT) }\end{array}$ \\
\hline $\begin{array}{l}\text { Interpreation } \\
\text { Program for the } \\
\text { Historic Centre of } \\
\text { Gracias / } 2005\end{array}$ & Municipality & $\begin{array}{l}\text { Local Tourism } \\
\text { Chamber }\end{array}$ \\
\hline $\begin{array}{l}\text { Diagnosis of the } \\
\text { Agrotourism } \\
\text { potential of } \\
\text { Mancomunidad de } \\
\text { Colosuca / } 2006\end{array}$ & $\begin{array}{l}\text { Mancomunidad } \\
\text { Colosuca }\end{array}$ & $\begin{array}{l}\text { IHT, Spanish } \\
\text { Agency for } \\
\text { Cooperation and } \\
\text { Development } \\
\text { (AECID) }\end{array}$ \\
\hline $\begin{array}{l}\text { Regulation } \\
\text { governing the } \\
\text { Protection of the } \\
\text { Historic Centre of } \\
\text { Gracias / } 2007\end{array}$ & Municipality & $\begin{array}{l}\text { Mancomunidad } \\
\text { Colosuca }\end{array}$ \\
\hline $\begin{array}{l}\text { Strategic Plan for } \\
\text { the Development } \\
\text { of the } \\
\text { Mancomunidad de } \\
\text { Colosuca / 2012- } \\
2022\end{array}$ & $\begin{array}{l}\text { Mancomunidad } \\
\text { Colosuca }\end{array}$ & $\begin{array}{c}\text { AECID, PNUD, } \\
\text { National Institut for } \\
\text { Conservationand } \\
\text { Forestry } \\
\text { Development (ICF), } \\
\text { Mancomunidad } \\
\text { Mapance, Technical } \\
\text { Secretariat for } \\
\text { International } \\
\text { Cooperation } \\
\text { (SEPLAN), } \\
\text { Municipalities }\end{array}$ \\
\hline $\begin{array}{l}\text { Management } \\
\text { Plan for the } \\
\text { National Park of } \\
\text { Celaque / 2012- } \\
\text { 2014 }\end{array}$ & $\begin{array}{l}\text { Mancomunidad } \\
\text { MAPANCE }\end{array}$ & $\begin{array}{c}\text { United States } \\
\text { Agency for } \\
\text { International } \\
\text { Development } \\
\text { (USAID) ProParque }\end{array}$ \\
\hline $\begin{array}{l}\text { Public Use Plan } \\
\text { of Celaque / } 2014\end{array}$ & $\begin{array}{l}\text { Mancomunidad } \\
\text { MAPANCE }\end{array}$ & $\begin{array}{c}\text { USAID ProParque, } \\
\text { ICF, IHT, IHAH, } \\
\text { Honduran National } \\
\text { Tourism Chamber } \\
\text { (CANATURH) }\end{array}$ \\
\hline $\begin{array}{l}\text { Urban } \\
\text { Development Plan } \\
\text { for Gracias / 2014- } \\
2025\end{array}$ & Municipality & $\begin{array}{l}\text { Mancomunidad } \\
\text { Colosuca }\end{array}$ \\
\hline $\begin{array}{l}\text { Local Economic } \\
\text { Developement } \\
\text { Agenda of } \\
\text { Gracias, Lempira / } \\
2015 \\
\end{array}$ & Municipality & $\begin{array}{l}\text { Local Tourism } \\
\text { Chamber, IHT }\end{array}$ \\
\hline $\begin{array}{l}\text { Strategic Plan for } \\
\text { the Sustainable } \\
\text { Tourism } \\
\text { Development of } \\
\text { Colosuca } \\
\text { destination / } 2016\end{array}$ & $\begin{array}{l}\text { Mancomunidad } \\
\text { Colosuca }\end{array}$ & IHT, AECID \\
\hline
\end{tabular}

Table 2. Instruments for heritage and tourism management governing the historic centre of Gracias 


\section{DISCUSSION AND CONCLUSIONS}

The comparative analysis of other historic centres shows that all of them met UNESCO's criterion iv for designation. This is one of the most common criteria for this type of heritage, as it perfectly reflects the characteristics of this type of heritage. For criterion iv, it was found that the city of Gracias meets the requirements of this criterion in the same way as the other cities did.

Through the study of other historical centres, it has also been possible to verify that the designated cities have similar origins and attributes to those of Gracias. Most of them date back to the 16th century, and they have the same original Plaza Mayor acting as an urban generator where official functions take place.

Moreover, this is reflected in the urban appearance, and in the growth of these towns. Similar outstanding universal values and comparable attributes of integrity and authenticity have been identified both in the cases study and in the historic centre of Gracias, based on the urban layout and building style.

Therefore, it can be deduced that, in terms of the integrity, authenticity and good conditions of its 16th-century setting, forms, materials and construction techniques, the town of Gracias accomplishes UNESCO requirements.

A remarkable trait for Gracias is that the social sustainability is guaranteed because most of its buildings are still being used for their original purposes and the historic centre has therefore retained its original residential role.

But the originality of the case of Gracias most certainly comes from the Lenca indigenous culture, which endures in the city's life as manifested in the several local festivities and events. Gracias maintains its harmony and lifestyle, as well as its respect for the natural environment that forged a cultural landscape that has been maintained for almost 500 years.

Regarding the managing and protection of the heritage, planning and management tools have been already developed and implemented in order to preserve built Heritage following the UNESCO's suggestions to become a World Heritage Site.

Nevertheless, it must be noted that historic colonial centres are overrepresented in the UNESCO List at regional American scale. For this reason, it is important to highlight the historical values of Gracias through reference to the presence of the 'Audiencia de los Confines' in the city, the influence of the Lencas' intangible heritage and the city's framing within its cultural landscape, all factors which mark Gracias out when compared to comparable Latin American towns.

\section{REFERENCES}

Castillo, E., 2018. Análisis comparativo de casos de estudio en América para la elaboración de la propuesta de inscripción del Centro Histórico de Gracias (Lempira, Honduras) en la lista de patrimonio mundial de la UNESCO. Universitat Politècnica de València. http://hdl.handle.net/10251/114340

Ceballos, M.M., Olayo, J., Alvarado, S., Martínez, D.A., Sosa, G. y Mejía, K., 2014. Plan de Desarrollo Urbano de Gracias, Lempira (ejecutivo), 2014-2025. Alcaldía Municipal de Gracias, Lempira (Honduras).
Fiallos, C., 1989. Los municipios de Honduras. Universidad Nacional Autónoma de Honduras, Editorial Universitari, Tegucigalpa.

Joya, O., 2011. El patrimonio tangible e intangible de la Mancomunidad de Colosuca. Honduras. Agencia Española de Cooperación Internacional para el Desarrollo, Tegucigalpa.

Rivera Tovar, J. E., 2009. El terremoto de 1915 en la ciudad de Gracias. Honduras. Ediciones Guardabarranco, Tegucigalpa.

Rubio Mañé, J.I., 1955. El Virreinato. Origenes y jurisdicciones $y$ dinámica social de los virreyes. Instituto Investigaciones históricas de la UNAM, Ciudad de México.

Viñals, M.J., Martínez-sanchís, I., Mayor, M., Teruel, L., Alonso-Monasterio, P., Rivera, M., 2016. Plan Estratégico de Desarrollo Turístico Sostenible del Destino Colosuca. Informe Técnico, Mancomunidad Colosuca.

UNESCO, 1972. Convención Sobre la Protección del Patrimonio Mundial, Cultural y Natural. UNESCO World Heritage Centre. http://whc.unesco.org/archive/conventiones.pdf. (4 April 2020).

UNESCO World Heritage Centre, 2011. Preparing World Heritage Nominations. UNESCO World Heritage Centre. https://whc.unesco.org/document/116069 (4 April 2020).

UNESCO World Heritage Centre, 2019. Operational Guidelines for the Implementation of the World Heritage Convention. UNESCO World Heritage Centre. https://whc.unesco.org/en/guidelines/ (4 April 2020).

UNESCO World Heritage Centre, 2020a. World Heritage List. Paris. https://whc.unesco.org/en/list/ (2 April 2020).

UNESCO World Heritage Centre, 2020b. World Heritage List. Protective town of San Miguel and the Sanctuary of Jesús $\begin{array}{lll}\text { Nazareno de Atotonilco. } & \end{array}$ https://whc.unesco.org/en/list/1274/ (2 April 2020).

UNESCO World Heritage Centre, 2020c. World Heritage List. Historic Centre of Santa Cruz de Mompox. Paris. https://whc.unesco.org/en/list/742/ (2 April 2020).

UNESCO World Heritage Centre, 2020d. World Heritage List. Historic Quarter of Colonia del Sacramento. Paris. https://whc.unesco.org/en/list/747/ (4 April 2020).

UNESCO World Heritage Centre, 2020e. World Heritage List. Historic Centre of Antigua Guatemala. Paris. https://whc.unesco.org/en/list/65/ (4 April 2020).

UNESCO World Heritage Centre, 2020f. World Heritage List. Historic Colonial Centre of Santo Domingo. Paris. https://whc.unesco.org/en/list/526/ (4 April 2020). 